\title{
ROMANESQUE CATHEDRALS IN NORTHERN ITALY - BUILDING PROCESSES BETWEEN BISHOP AND COMMUNE
}

\author{
Bruno Klein
}

If we examine the role of patrons in the Middle Ages, we make an unconsciously clear distinction between institutional and individual patrons, but it is by no means so simple to draw the line. For example, if a bishop commissioned the rebuilding of a cathedral, then he may have been personally interested, and this special person was certainly someone of more active than passive temperament. Nevertheless, in this case he acted not as an individual person but as a representative of an institution, because, according to canon law, it was the duty of a bishop to ensure the existence of an adequate cathedral. If, however, a cathedral chapter cared for the building of a cathedral - which was generally the case - then conversely we should expect that some specific member was particularly engaged and involved. In fact, the chapter didn't manage the fabrica as a group, but it entrusted individual members with its management.' So it is not easy to distinguish individuals and institutions. And what about lay founders? Did they act as individuals, or as groups, or as members of an institution, a family and so on?

A second problem is that people and institutions are not and were not immutable. People change, just as institutions do, although institutionalisation actually has a goal in stabilisation. Medieval building processes often provided an opportunity to change the role of individuals and institutions as well as their relationships to each other. ${ }^{2}$ A building process was even able to develop the role and the status of its patrons, not only in what concerned their position in relation to the building, but also in their social position in general.

Finally, institutions and individuals are notions that are only historically well defined. Neither institutions nor individuals have remained the same from the Middle Ages to the present day, nor stayed unaltered in such a very short period as the 12 th century. A look at some very well-known buildings in northern Italy should help to exemplify such ideas about uncertainty, change and development during medieval building processes.

All these elements were relevant for the Romanesque cathedral of Modena (Figure 3.1). ${ }^{3}$ Its construction began in 1099. The famous Relatio corporis sancti Geminiani, ${ }^{4}$ the report on the events surrounding the construction of the new church, informs us that the ancient church was at this time too old, too small and threatened collapse, a situation that led the inhabitants of Modena to decide to build a new one. It is reported that in fact all the residents of the city shared this desire: the clerics, the knights and the citizens. All but one: at that moment Modena did not have a bishop, who was traditionally the lord of the city. The fact that the construction of the new building began at a time of sede vacante, is expressly mentioned by the Relatio. It would be very surprising if the people of Modena had, just in the period in which there was no bishop, noticed that their cathedral was too small and too ruinous, and then spontaneously began, even before a new bishop could be chosen, to start a new building. As mentioned, the commission and furnishing of a cathedral belonged to the rights and the duties of a bishop. So starting to rebuild a cathedral in the period of sede vacante was a very clear and mainly critical statement. The legal, but former, responsible institutional patron was replaced by a new one. And so the game became open, because at that moment the inhabitants of the city did not yet represent something comparable to a well-organised institution. Instead they were a very heterogeneous group of people with different interests and different statuses of self-organisation. An ancient institution - the bishop - was challenged by a new one - the city. The ancient institution was personally absent, and the new one still was not organised. The commune of Modena was only established some decades later. So we can observe a conflict between two institutions which were both at that very moment quite weak - but the first descending and the second ascending (Figure 3.2).

So it therefore cannot be surprising, that in the years after 1099 even the pope and the countess Matilda of Tuscany engaged themselves in the affairs of the rebuilding of Modena cathedral. They did it, both because the situation inside of the city of Modena was too unstable and needed external stabilisation - and, on the other hand, that unstable situation gave the opportunity for external forces to engage themselves, with the aim to profit from that uncertainty.

Regarding the further history of the building history of Modena cathedral, we can observe that the conflicts between the different parties continued: when, for example, it became necessary due to the building progress 


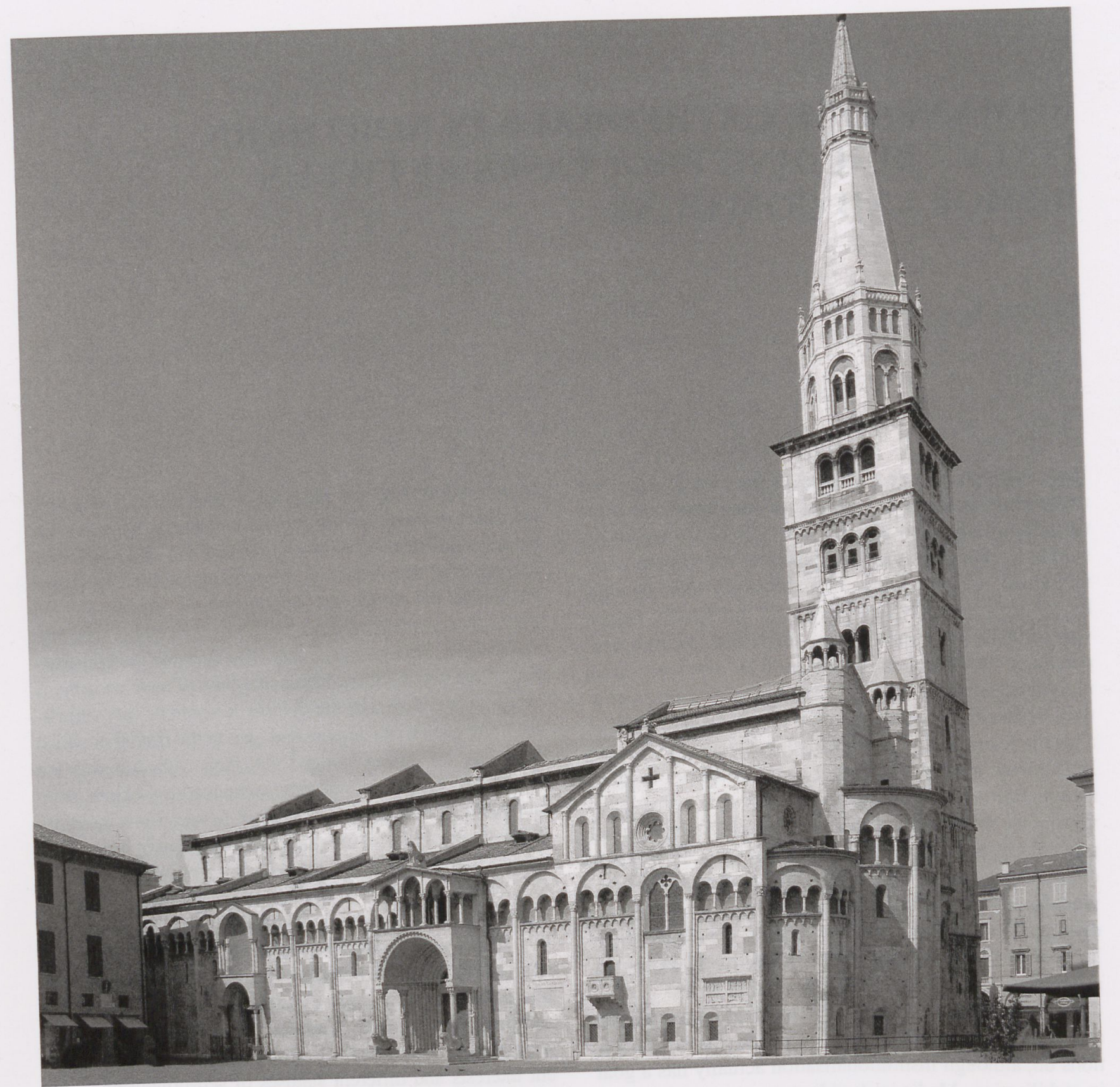

FigURE 3.1

Modena Cathedral: Exterior from south-east (after Giopie, Wikimedia)

to translate the relics of the patron saint of the city, San Geminiano, in 1106, it was extremely difficult to resolve the problem of how to manage that move, due to the extreme suspicion between the different parties. Each of them feared that the others would take possession of the relics. It is very surprising to see that in the end the new bishop and the architect of the building, named Lanfrancus, carried the relics together. It seems that the bishop became able to fulfill that very difficult task, because he had lost importance during the building process and was now able to act more freely. On the other hand, it is astonishing to see how an architect, hitherto nearly unknown as person or institution, could obtain such an important role. It seems that building processes were able to open and to set moving historically fairly closed constellations.
Unfortunately, we don't have any precise information about the circumstances of the building of the Romanesque cathedral of Cremona, which started in 1107. But there is no doubt, that in this year the bishop's throne of Cremona was empty. ${ }^{5}$ (Figure 3.3 ) The famous inscription which reports the start of the construction in this very year, mentions only the bishop of Rome, Pope Paschal II, but the name of the local bishop is passed over in silence.

Historical information is a little bit better in the case of the construction of the Romanesque cathedral in Piacenza: here, building started most likely in 1122, as is reported by an inscription on the south porch. Although the inscription is actually modern, its literal correctness is well demonstrated by ancient documents. ${ }^{6}$ Is it astonishing that 1122 was also the year in which Aldo, count-bishop 


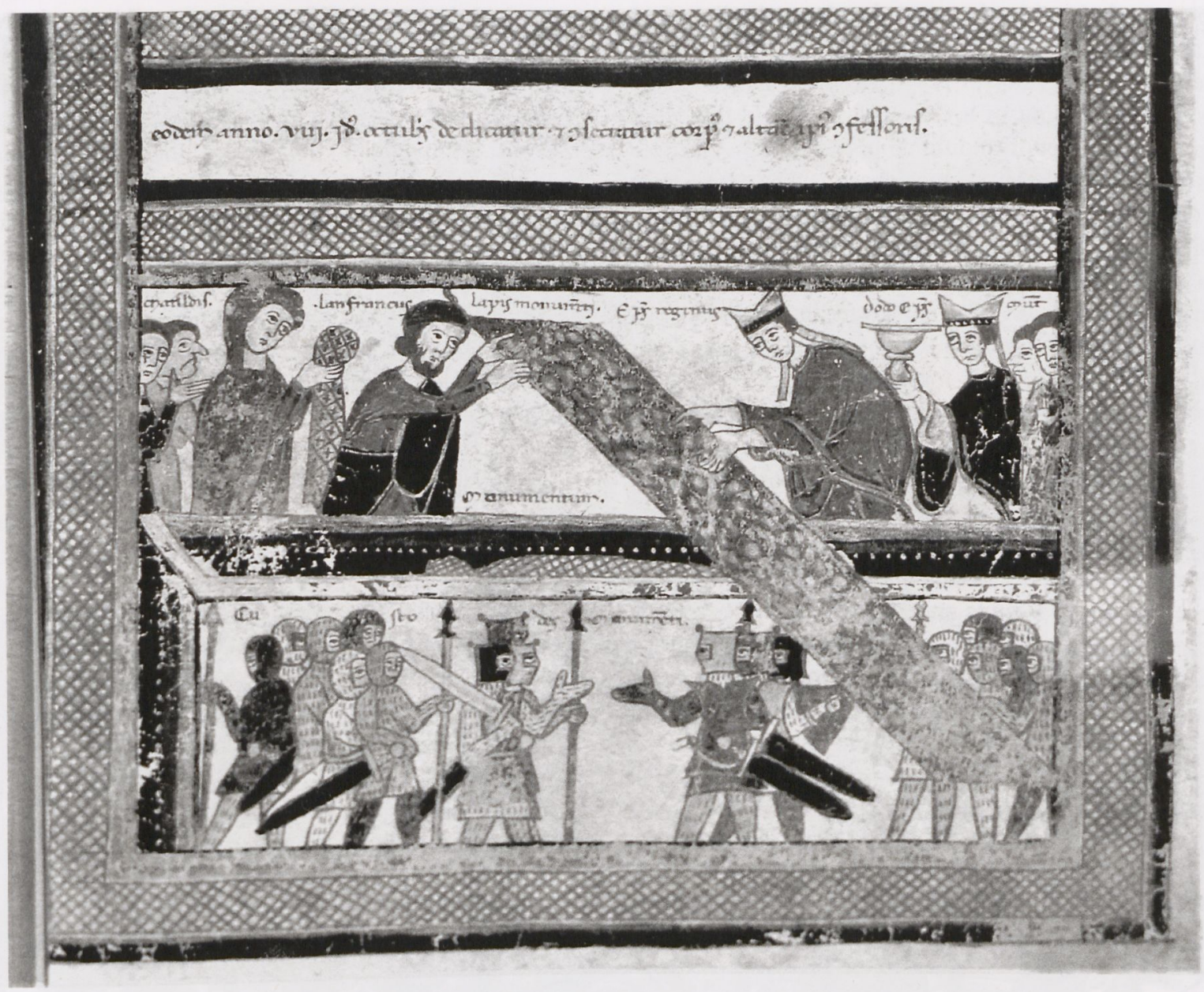

Figure 3.2

Modena, Archivio capitolare di Modena MS II.11, fol. 9r: Translation of the relics of S. Geminiano

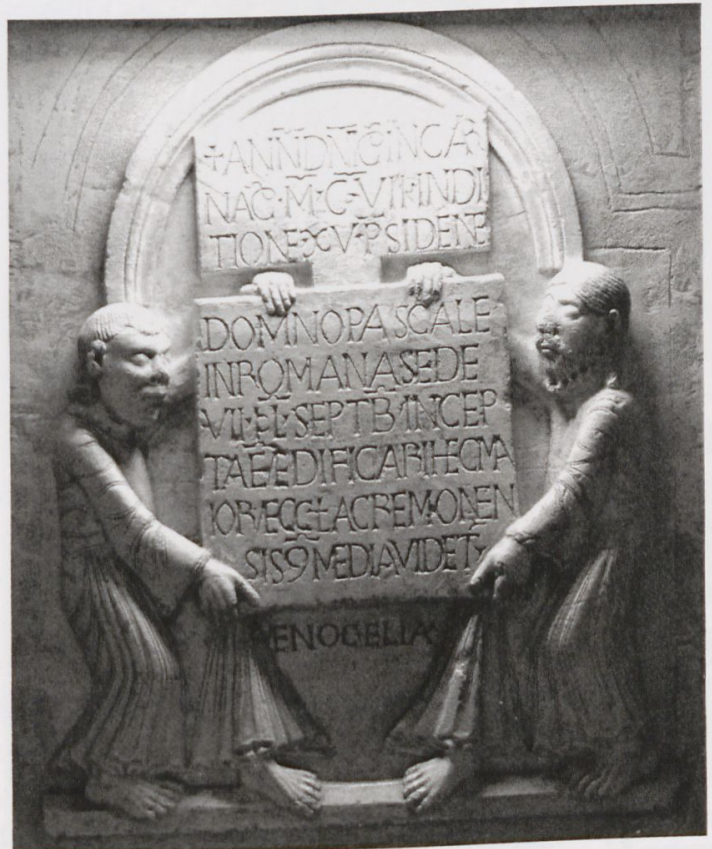

FIGURE 3.3

Cremona Cathedral: Plaque recording the foundation of the Romanesque cathedral (Renzo Dionigi) of Piacenza for nearly 25 years, died and his successor, named Arduino, was elected? ${ }^{7}$ Only four years later, in 1126, the 'consuls' of the city were mentioned for the first time. This doesn't mean that the office of the 'consul' was created exactly at that moment, because consuls normally appeared in written records only some time after the installation of that office. But it is certain that the existence of consuls always indicates the achievement of a certain degree of autonomy of a commune. So it seems quite likely that there were connections between the change in the episcopate, the beginning of the construction of a new cathedral and the creation of the commune of Piacenza. ${ }^{8}$ Here it is possible to observe social instability combined with a new political dynamic, and cathedral-building as a means in the struggle between old forces and new claims.

As in Modena, the commune of Piacenza wasn't yet able to act as a well-organised institution. In consequence, its engagement could hardly influence directly the form or the style of the monument, because there were no means to do so. Nevertheless, the new patrons weren't without any consequences on the layout of a new church: as we know from many cases of rebuilt churches in the Middle Ages, the clergy generally tried to maintain the ancient liturgical topography in the new building. Thus 
the special relationships between the altars, the liturgical choir and so on remained unchanged. When a new patron, or even an entire group of new patrons, engaged themselves in the building of a church, how could they find their place in the set of traditional holy places?

It is possible to observe some consequences of this shift at the cathedral of Piacenza. The building is clearly divided into different sections: There is a liturgical choir, situated over a very spacious crypt. Here, the reliquary of the saint patrons of the cathedral was exhibited, and according to the ancient book of ceremonies of the cathedral, the crypt served as the winter church for the chapter. ${ }^{9}$ So it is quite evident that the eastern part of the cathedral was mainly reserved for the clergy, and that the clergy tried also to be in the possession of the cathedrals most important relics.

The laity had the nave and the transept, both quite spacious, with their own entrances and porches. In this part of the church, above the arcade of the central nave, there are reliefs of female saints and of prophets - the former on the south side, the latter on the north side (Figure 3.4). This is now a unique representation - not found in any other church - but such representations could also have been painted and are now lost. It is interesting to observe that the relics of saints were in the crypt, where the clergy was present, and the representations of saints in the nave, were the laity stayed. Who was responsible for the representation of the saints and prophets in the nave? And why were they shown? Because the laity wished to be among the saints? Or was it the wish of the clerics to show the supreme dominance of the saints in the entire cathedral?

Prophets are quite often to be found on the façades of Romanesque cathedrals in Northern Italy, ${ }^{10}$ and sometimes, as in Cremona, they are holding long inscriptions, related probably to popular religious performances. ${ }^{11}$ The female saints of Piacenza are the Virgin Mary and Saint Giustina, the two patrons of the cathedral, followed by Saint Candida and Saint Paolina. The relics of these two saints probably came to Piacenza only in $1120 .{ }^{12}$ Finally there is Saint Margaret, one of the most popular saints of the time. In contrast to this inflation of female saints in the nave of the cathedral, there is a conspicuous lack of representation of male saints: images are lacking of the martyr San Antonino, patron of the former cathedral of Piacenza, or of the two holy bishops of the city, San Vittore und San Savino. In the absence of any written source to explain the phenomenon, it is only possible to state that in the nave of the cathedral there is a richer and even more innovative figurative decoration than in its eastern parts, choir and crypt.

It is also only in those western parts of the cathedral that we find some other, very uncommon, reliefs of the 12 th

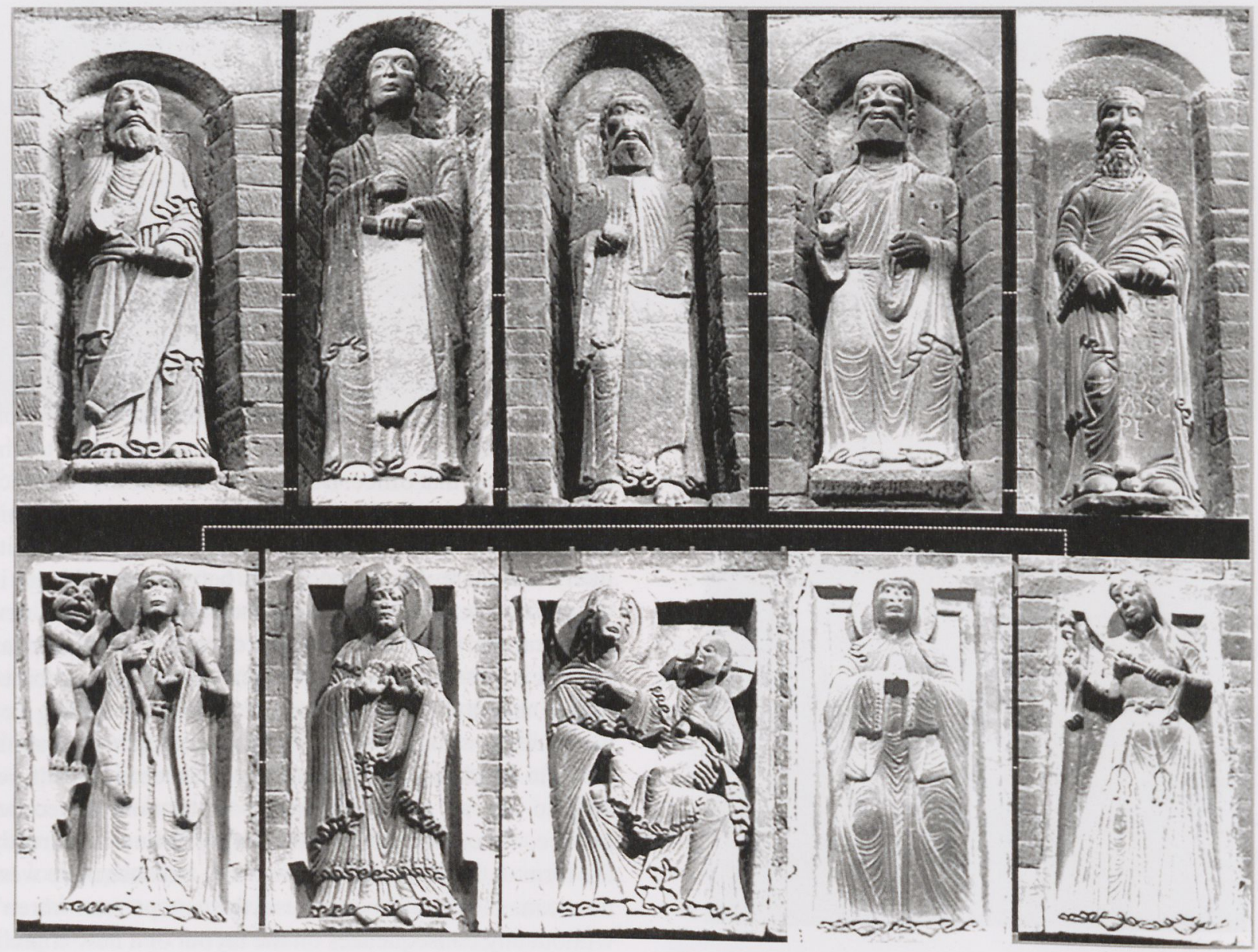

FiguRE 3.4

Piacenza Cathedral: Nave reliefs of saints and prophets (Bruno Klein) 


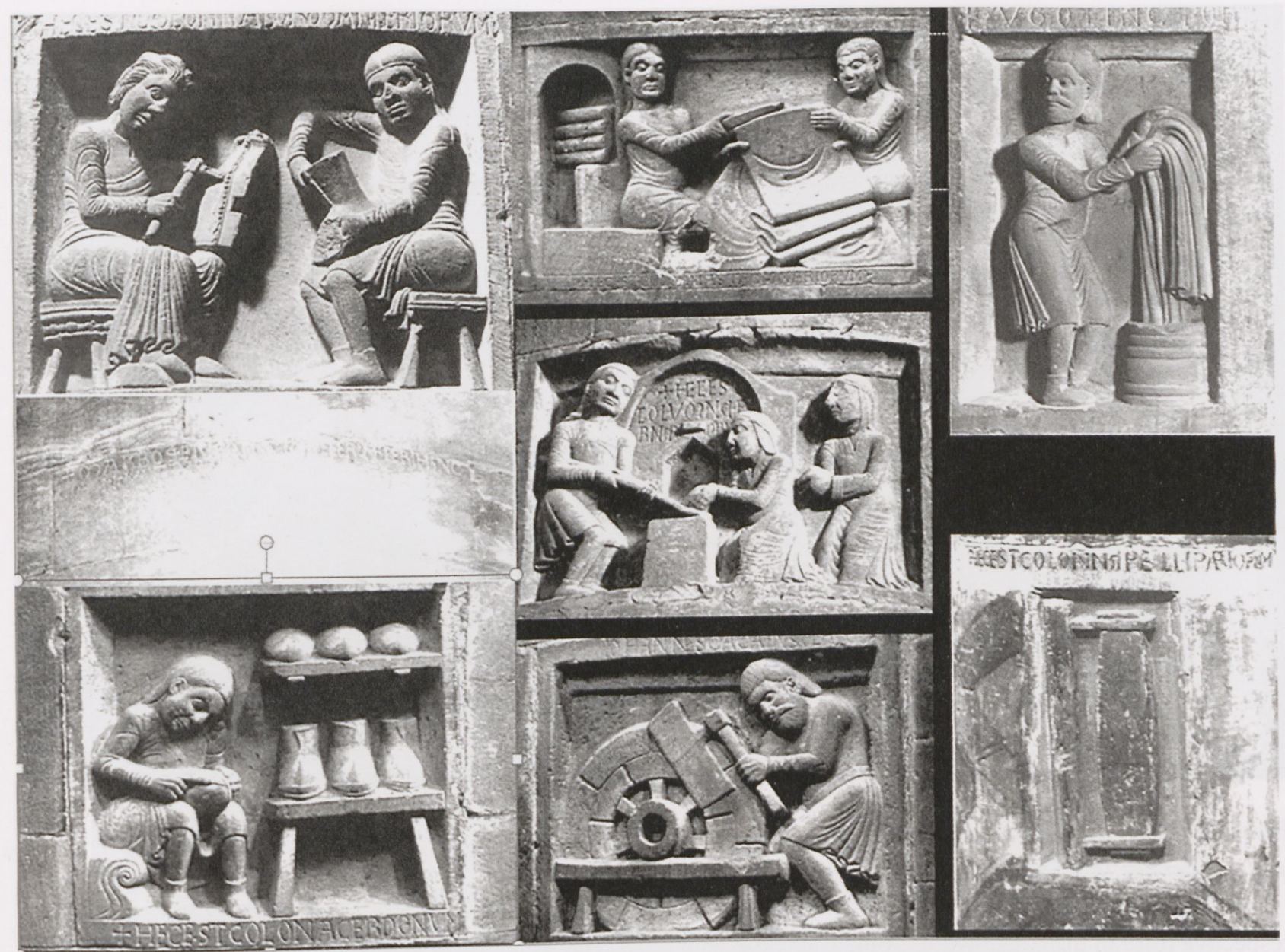

FIGURE 3.5

Piacenza Cathedral: Nave reliefs of lay patrons (Bruno Klein)

century (Figure 3.5). They are integrated in the pillars, and represent lay persons who without doubt contributed to the construction of the cathedral, because the reliefs are accompanied by inscriptions, saying that the columns were almost in the possession of those people: 'haec est columna - 'this is the column' of the represented person is the usual formulation of the inscriptions. ${ }^{14}$ It is obvious that there must be some relation between the representations of the lay founders and the saints above them. Maybe, that those citizens were less interested in the representations of saint bishops, counterparts of the ecclesiastical lord of the city, than in images of more 'modern' and more 'popular' saints, which could not easily be claimed by one or another party of the society at Piacenza.

But that would only be pure speculation. It is more instructive to examine and to compare the reliefs which seem to show singular persons or groups of persons, responsible for the foundation of the respective pillar (Figure 3.6). There is only one pure verbal description without any pictorial representation, mentioning 'Ugo tinctor' and, as far as it is possible to read that inscription, 'Maria Bos', together as the patrons of that pillar. The Latin reads: 'Maria Bos et Vgo tinctor fecerunt fieri hanc colonam in templo d[omi]ni' - Maria Bos and Ugo Tinctor had made this column in the temple of the Lord. The same Ugo tinctor,
Hugh the dyer, is represented on another pillar as donor, but this time pictorially and as an individual person. On that relief, Ugo is shown as he is taking a cloth out of the vat. This is not the representation of any special action to underline the importance of $\mathrm{Ugo}$ for the social interaction in Piacenza, but it shows him as a wealthy individual, able and obviously willing to contribute to the construction of the city's cathedral. There is only one other relief showing such an individual person as patron of a pillar. It is the relief of 'Johannes caca in solario', John in his workshop, a wheelwright shown in action (Figure 3.6).

It is conspicuous that neither Ugo nor Johannes was explicitly mentioned as founder or patron of the column on which they are pictorially represented. So it seems that there was a certain restraint, avoiding an excessive highlighting of any individual person. On the other hand, the possessive inscriptions 'haec est colonna ...'- this is the column of ...., are exclusively reserved for groups with anonymous members. Among these we find two times the shoemakers, the tailors, the tanners and the bakers or oven owners. Clearly only groups of craftsmen or growing institutions had the right to declare a column as their own; individuals, however, had to be content with more modest hints. That indicates that there must have been a certain debate between individuals and groups, concerning their 


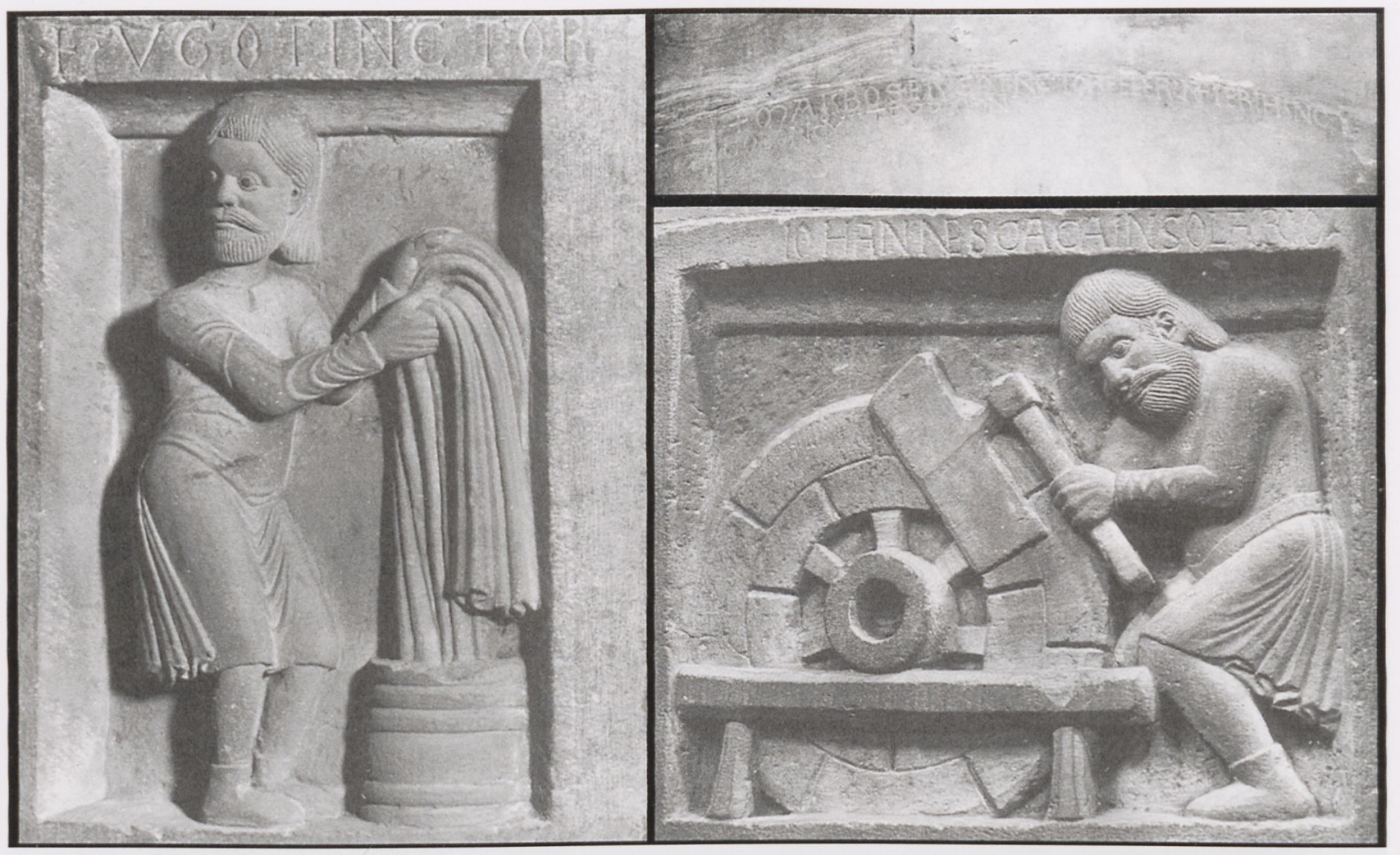

Figure 3.6

\section{Piacenza Cathedral: Nave reliefs of Ugo and Johannes (Bruno Klein)}

respective roles in the construction of the Cathedral, and that problems of representation were solved by the diversity of representations and inscriptions.

The staging of individuality in the support of the construction of the cathedral was probably not desired or even highly regarded, because the aforementioned Ugo and Johannes hide themselves under the mantle of artisans, so as to appear similar to the other supporters. Individuals or not, the donors are all represented in action with their tools and their objects prominently placed and mostly large in scale (Figure 3.7). Comparing for example the shoes which the shoemakers are producing to the shoes on their feet, the disproportion is nearly grotesque. In consequence, it is necessary to distinguish two layers in the staging of the foundation of the cathedral. The first, and stronger, one was to be an active member in and for the city. The second was focussed on individual memoria, but its staging was absolutely overlaid by the first one.

It may be that the production of monuments of individual memoria was a very typical feature of the ancient nobility, and that modern communal burghers tried to distinguish themselves from that tradition - without being really able to ignore the attraction of that feature. So the only inscription mentioning a very individual sponsorship, 'Maria Bos et Vgo tinctor fecerunt fieri hanc colonnam', with the emblematic phrase 'fecerunt fieri', literally copied from a prominent deed of foundation, had to disappear into the shadows of a quite invisible part of the cathedral and it is nearly impossible to find that inscription.
The reliefs seem to indicate that the guilds of Piacenza were the most important supporters of the construction of the cathedral. But there were not, as yet, any guilds in Piacenza in the second quarter of the 12th century, during the erection of those columns. So the reliefs give an insight into the formation of those institutions. More specifically, building and financing the cathedral contributed to the development and definition of those institutions, and generated differences between donations made by institutions and individuals as well as between the sponsorship of ecclesiastics and the laity.

Close examination and the reconstruction of quite different cases, mainly of Modena and Piacenza, not only gives some hint of the political and social situation in those cities at the end of the 11th and the beginning of the 12th century, but it also delivers information about the possibilities and representation of patronage in those cities. It is also possible to observe that unstable or critical relations between potential founders led to innovative solutions to represent their donations. If it is impossible to reconstruct the discussions about how to build and to patronize a cathedral building, the artistic effects of those discussions are perfectly visible. Finally: building a major city-church gave not only the possibility to redefine the role of different groups of founders, but it also offered the chance to claim and to establish new rights. There is no doubt that moments of political and social uncertainty were ideally suited to stage such claims. So the absence of an ancient force - the bishop - and the presence of a new one - the members of the commune - is no coincidence, but the condition for the creation of a new art. It would be interesting 


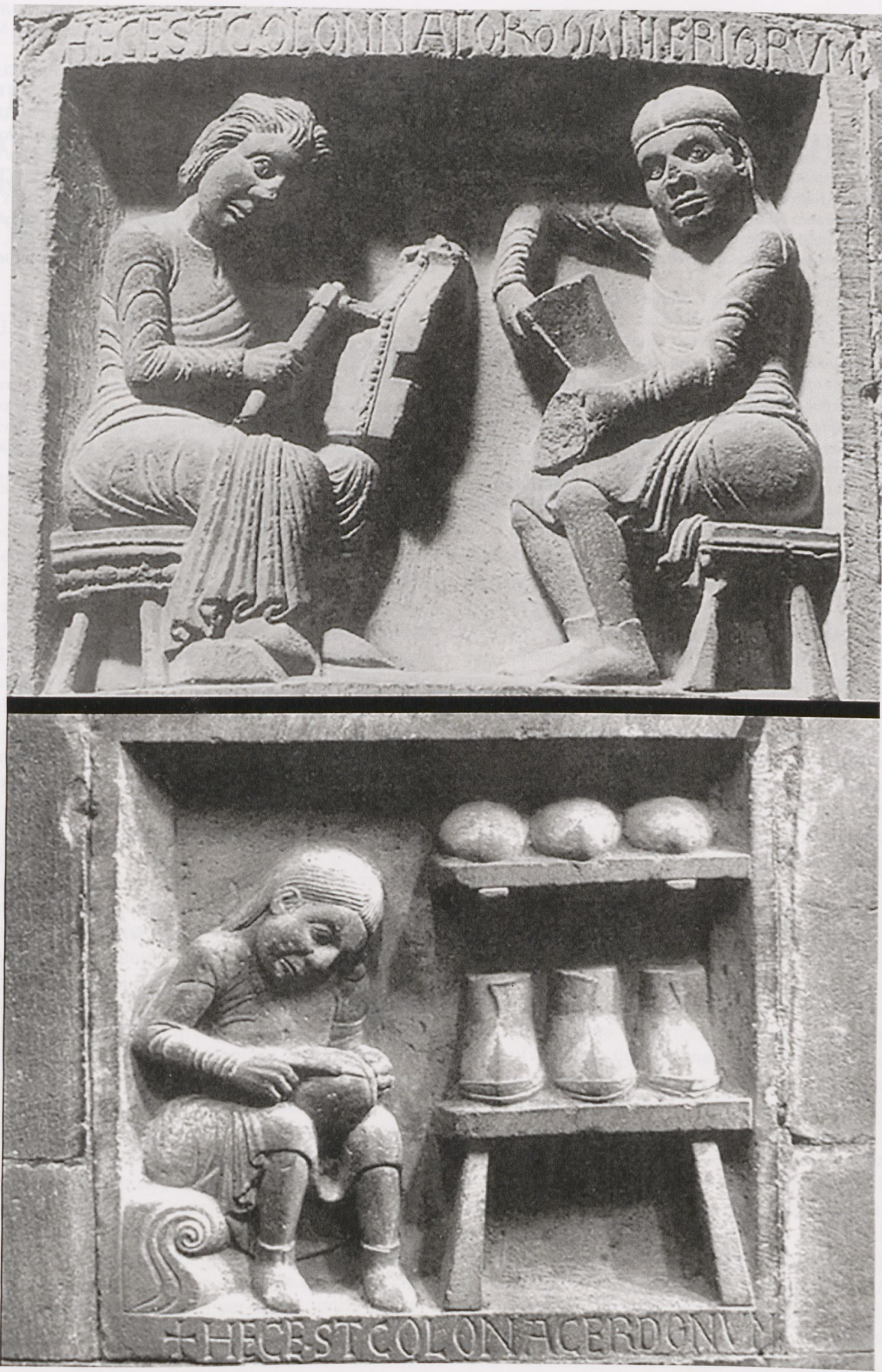

FIGURE 3.7

Piacenza Cathedral: Reliefs of donors (Bruno Klein) 
to analyse systematically when and where such situations arose, and to reconstruct the impact they had on this art.

\section{NOTES}

W. Schöller, Die rechtliche Organisation des Kirchenbaues im Mittelalter, vornehmlich des Kathedralbaues:Baulast, Bauherrenschaft, Baufinanzierung (Köln 1989).

2 B. Klein, 'Bauen bildet. Aspekte der gesellschaftliche Rolle von Bauprozessen mittelalterlicher Großbaustellen', in: Kirche als Baustelle : große Sakralbauten des Mittelalters, ed. K. Schröck, B. Klein and S. Bürger (Köln 2013), 11-22.

The bibliography on Modena Cathedral is abundant, so I mention only some recent or classic studies: P. Bonacini, La fabbrica di San Geminiano: regesto del codice capitolare O.II.11. (Modena 2012); A. Peroni, 'La cripta del Duomo di Modena e l'avvio della costruzione dell' architetto Lanfranco', Westfalen, 87 (2009), 13-42; D. Glass, The Sculpture of Reform in North Italy, ca. 1095-1130. History and Patronage of Romanesque Façades (Farnham 2010); E. Castelnouvo and A. Peroni eds, Wiligelmo e Lanfranco nell' Europa romanica (Modena 1989).

4 Relatio translationis corporis sancti Geminiani, M.XC.LX-M.C.V, ed. G. Bertoni, Raccolta degli Storici Italiani dal cinquecento al millecinquento, 4 (Citta di Castello 1907), (https://openlibrary.org/books/OL24983657M/ Relatio_translationis_corporis_sancti_Geminiani_M.XC.IX-M.C.VI).
5 Glass, Sculpture of Reform (as n. 3) 203-14; A. Calzona, Il cantiere medievale della cattedrale di Cremona (Cinisello Balsamo - Milano 2009); A. Puerari, Il duomo di Cremona (Milano 1971).

6 B. Klein, Die Kathedrale von Piacenza. Architektur und Skulptur der Romanik (Worms 1995), 15, n. 18.

D. Glass, Sculpture of Reform (as n. 3), 214-28, favours slightly different dates for the death of Aldo and the official start of his successor Grimerio. But I am in no doubt that the construction of the new cathedral began at about the time of the episcopal change.

8 On the relations between bishop and commune, especially at Piacenza see: P. Racine: 'I vescovi e il governo comunale', Il Medioevo. Dalle Riforma gregoriana alla vigilia della Riforme protestante, Storia della Diocesi di Piacenza 2, P. Pierre Racine ed, (Brescia 2009), 96-123.

9 B. Klein, Piacenza (as n. 6), 74.

10 D. Glass, Sculpture of Reform (as n. 3), 175-81.

11 D. Glass, Sculpture of Reform (as n. 3), 207-14.

12 B. Klein, Piacenza, (as n. 6), 15, n. 18.

13 In the eastern parts of the church there is only one figurative capital with scenes of Abraham's life, exactly between nave and choir. However, there are several figurative capitals in the nave: for example on the inner side of the façade with scenes of David and the stoning of Stephen, or in the North transept with Samson and the Lion.

14 B: Klein, "Die "Scuola di Piacenza",", in Studien zur Geschichte der europäischen Skulptur im 12./13. Jahrhundert, ed. H. Beck and K. Hengevoss-Dürkop (Frankfurt 1994), 1, 651-64 